\title{
PERBEDAAN NILAI PDW, MPV, DAN JUMLAH TROMBOSIT PADA PRE DAN POST HEMODIALISA PASIEN GAGAL GINJAL KRONIK
}

\author{
Sri Ujiani $^{1}$, Maria Tuntun ${ }^{2}$, Tiatira Magdalena Rentha Hasibuan ${ }^{3}$ \\ ${ }^{1}$ Prodi Diploma IV Analis Kesehatan Poltekkes Tanjungkarang \\ ${ }^{2}$ Prodi Diploma III Analis Kesehatan Poltekkes Tanjungkarang \\ ${ }^{3}$ Alumni Prodi Diploma IV Analis Kesehatan Poltekkes Tanjungkarang
}

\begin{abstract}
Abstrak
Pada proses hemodialisa, terjadi aliran darah di luar tubuh yang mengakibatkan terjadinya aktivasi sistem koagulasi darah dengan akibat timbulnya bekuan darah. Pasien-pasien dengan penyakit ginjal kronis memiliki risiko kehilangan darah pada proses hemodialisa. Trombosit memiliki peran penting yaitu melindungi integritas endotel pembuluh darah dan dalam proses hemostasis apabila terjadi kerusakan pada dinding pembuluh darah. MPV (Mean Platelet Volume) merupakan petanda fungsi trombosit dan berhubungan dengan penunjuk aktivitas trombosit. PDW (Platelet Distribution Width) mengukur variasi ukuran trombosit yang beredar dalam darah perifer. Tujuan dari penelitian ini adalah untuk mengetahui perbedaan nilai PDW, MPV dan jumlah trombosit pasien gagal ginjal kronik pada pre dan post hemodialisa di RSUD dr. H. Abdul Moeloek Provinsi Lampung. Jenis penelitian ini adalah analitik dengan pendekatan cross sectionaldengan uji t Paired sample test. Penelitian ini dilakukan di RSUD dr. H. Abdul Moeloek Provinsi Lampung, pada bulan Mei 2017. Populasi dari penelitian ini yaitu 30 pasien gagal ginjal kronik yang menjalani hemodialisa. Hasil penelitian menunjukkan bahwa variabel jumlah trombosit pasien GGK pada pre dan post hemodialisa memiliki perbedaan nilai yang bermakna, dengan nilai p-value 0.000. Sedangkan pada variabel nilai PDW dan Nilai MPV pasien GGK pada pre dan post hemodialisa tidak memiliki perbedaan nilai yang bermakna dengan nilai p value 0.088 dan 0.725 .
\end{abstract}

Kata Kunci : PDW, MPV, Jumlah Trombosit, Hemodialisa

\section{DIFFERENCE VALUE PDW, MPV, AND TROMBOSIT ON PRE AND POST HEMODIALISA PATIENT CHRONIC RENAL FAILURE}

\begin{abstract}
In the process of hemodialysis, blood flow outside the body resulting in the activation of blood coagulation system with the result of blood clots. Patients with chronic kidney disease have a risk of blood loss in the hemodialysis process. Platelets have an important role to protect the integrity of blood vessel endothelium and in the process of hemostasis in the event of damage to blood vessel walls. MPV (Mean Platelet Volume) is a marker of platelet function and is associated with the indicator of platelet activity. PDW (Platelet Distribution Width) measures the variation in platelet size circulating in peripheral blood. The purpose of this study was to determine the difference of PDW, MPV and platelet counts of patients with chronic renal failure in pre and post hemodialysis in RSUD dr. H. Abdul Moeloek Lampung Province. The type of this research is analytic with cross sectional approach with t test Paired sample test. This research was conducted in RSUD dr. H. Abdul Moeloek Lampung Province, in May 2017. The population of this study were 30 patients with chronic renal failure who underwent hemodialysis. The results showed that the variable of platelet count of GGK patients in pre and post hemodialysis had significant difference value, with p-value 0.000 . While the variable of PDW value and MPV value of GGK patients on pre and post hemodialysis did not have significant difference value with pvalue value 0,088 and 0,725 .
\end{abstract}

Keywords: PDW, MPV, Platelet Count, Hemodialysis

Korespondensi : Sri Ujiani, Jurusan Analis Kesehatan Politeknik Kesehatan Tanjungkarang, Jl. Soekarno-Hatta No. 1 Bandar Lampung, mobile : 081540822571,e-mail : sriujiani123@yahoo.com 


\section{Pendahuluan}

Gagal ginjal adalah keadaan yang terjadi ketika ginjal tidak mampu mengangkut sampah metabolik tubuh dan melakukan fungsi regulernya. Suatu bahan yang biasa dieliminasi di urin menumpuk dalam cairan tubuh akibat gangguan ekskresi renal dan menyebabkan gangguan fungsi endokrin dan metabolik, cairan, elektrolit, serta asam basa. Gagal ginjal dibagi menjadi dua kategori yang luas, yaitu gagal ginjal akut dan gagal ginjal kronik (Price dan Wilson, 2012).

Gagal Ginjal Kronik (GGK) atau penyakit ginjal tahap akhirmerupakan gangguan fungsi ginjal yang progresif dan ireversibel dimana kemampuan tubuh gagal untuk mempertahankan metabolisme dan keseimbangan cairan dan elektrolit, menyebabkan uremia (retensi urea dan sampah nitrogen lain dalam darah) (Suharyanto, dkk, 2013). Tinjauan mengenai perjalanan umum gagal ginjal kronik dapat diperoleh dengan melihat hubungan antara bersihan kreatinin dengan laju filtrasi glomerulus (GFR) sebagai persentase dari keadaan normal, terhadap kreatinin serum dan kadar nitrogen urea darah (BUN) karena massa nefron dirusak secara progresif oleh penyakit ginjal kronik. Perjalanan klinis umum gagal ginjal kronik dibagi menjadi tiga stadium, stadium I yaitu penurunancadangan ginjal (faal ginjal antara 40 $\%-70 \%$ ), stadium II yaitu isufiensi ginjal (faal ginjal antara $20 \%$ - $50 \%$ ), dan stadium III yaitu uremi gagal ginjal (faal ginjal kurang dari $10 \%$ ) (Price and Wilson, 2012).

Berdasarkan hasil Riset Kesehatan Dasar (Riskesdas) menunjukkan adanya prevalensi penyakit gagal ginjal kronik sebagai salah satu penyakit kronis yang tidak menular di Indonesia yaitu sebesar $0,2 \%$, pada pasien laki -laki sebesar $0,3 \%$, lebih tinggi dari perempuan sebesar $0,2 \%$. Prevalensi penyakit gagal ginjal kronik yang terdapat di Provinsi Lampung menempati urutan ke 7, yaitu sebesar 0,3\% di Indonesia (Riskesdas, 2013:133).

Jumlah pasien gagal ginjal kronik terus meningkat setiap tahunnya.Pada tahun 2014 di Indonesia terdapat 17.193 pasien yang baru menjalani hemodialisa, jumlah ini mengalami peningkatan sebanyak 2.065 pasien dari tahun sebelumnya yaitu sebanyak 15.128 pasien yang menjalani hemodialisa di 358 unit di Indonesia (Pernefri, 2012). Hemodialisa adalah suatu teknologi tinggi sebagai terapi fungsi ginjal untuk mengeluarkan sisa-sisa metabolisme atau racun tertentu dari peredaran darah manusia seperti air,natrium, kalium, hidrogen, urea, kreatinin, asam urat, dan zat-zat lain melalui membran semi permeabel sebagai pemisah darah dan cairan dialisat pada

ginjal buatan dimana terjadi proses difusi, osmosis dan ultrafiltrasi (Haryono, 2013).

Pasien-pasien dengan penyakit ginjal kronis memiliki risikokehilangan darah pada proses hemodialisa. Kekurangan asam folat dalam proses hemodialisa dapat menyertai kejadian uremia, maka vitamin yang larut dalam air akan hilang melalui membran dialisis. Kecenderungan untuk mengalami pendarahan pada uremia agaknya disebabkan oleh gangguan kualitatif trombosit yang mengakibatkan gangguan adhesi. Hambatan pada faktor pembekuan juga ikut berperan (Price and Wilson, 2012).

Pada proses hemodialisa, terjadi aliran darah di luar tubuh. Pada keadaan ini akan terjadi aktivasi sistem koagulasi darah dengan akibat timbulnya bekuan darah. Karena itu, pada proses hemodialisa diperlukan pemberian heparin sebagai antikoagulasi. Kerja heparin sebagai antikoagulasi bergantung pada antitrombin (AT-III), yaitu suatu inhibitor dari berbagai faktor pembekuan. Heparin menyebabkan perubahan hemostasis karena efeknya terhadap fungsi trombosit (agregasi trombosit), bahkan menurunkan jumlah trombosit (Heparin Induced Thrombocytopenia). Nilai trombosit normal bila dilakukan pengontrolan ketat terhadap pemberian heparin, tidak akan memberikan efek samping yang banyak. Sedangkan dalam kasus pasien yang mengalami trombositopenia menunjukkan adanya efek samping dari heparin akibat dari penggunaan heparin yang berulang selama proses hemodialisa (Kaparang, dkk, 2013).

Trombositopenia akibat heparin yang tidak melibatkan sistem imun akan sembuh sendiri tanpa komplikasi serius, biasanya berlangsung dalam 4 hari setelah paparan pada $10-30 \%$ pasien yang mendapat heparin. Heparin berikatan kuat dengan trombosit, sehingga menghambat adenilsiklase dan menurunkan kadar cyclic adenosine monopasphate (cAMP) intraseluler. Akibatnya, ambang aktivasi trombosit akan menurun, terjadi agregasi trombosit dan trombositopenia (Roveny, 2016). Fungsi cAMP sendiri mengendalikan konsentrasi ion kalsium bebas dalam trombosit yang penting dalam proses adhesi dan agregasi trombosit (Hoffbrand, et al, 2013).

Trombosit merupakan sel tak berinti, berbentuk cakram dengan diameter 2-5 mm, 
berasal dari pertunasan sel raksasa berinti banyak megakariosit yang terdapat dalam sumsum tulang (Tarwoto, 2008).Trombosit mempunyai peranan penting dalam hemostasis yaitu pembentukandan stabilisasi sumbat trombosit. Pembentukan sumbat trombosit terjadi melalui beberapa tahap yaitu adhesi trombosit, agregasi trombosit, dan reaksi pelepasan (Setiabudy, 2012).

Seiring dengan perkembangan teknologi di bidang kedokteran di masakini, dalam penghitungan sel darah (sel darah merah, sel darah putih, dan trombosit) mulai digunakan alat yang teroganisir. Dengan tersedianya alat analisa sel darah secara otomatis, indeks pemeriksaan baru yang berkaitan dengan hitung jumlah trombosit juga dapat diperkirakan. Parameterparameter penting diantaranya adalah Plateletcrits (PCT), Mean PlateletVolume (MPV), dan Platelet Distribution Width (PDW). Aktivasi trombosit menyebabkan perubahan pada bentuk trombosit, dengan adanya peningkatan pada trombosit yang membengkak setara juga dengan peningkatan nilai MPV dan PDW. Nilai MPV sendiri sebanding dengan nilai Mean Corpuscular Volume (MCV) pada sel darah merah. Gabungan interpretasi nilai jumlah trombosit, MPV, dan PDW sangat berguna dalam membantu mendiagnosis terjadinya keadaan trombositosis. Penelitian sebelumnya telah dilakukan untuk mengetahui variasi nilai parameter pemeriksaan trombosit dalam kondisi klinis yang berbeda-beda (Shah, et al, 2013).

Penelitian sebelumnya yang dilakukan oleh Jesinta Kaparang, dkk tahun 2013 di Unit Hemodialisis Bagian/SMF Ilmu Penyakit Dalam FK UNSRAT BLU RSUP Prof. Dr. R. D. Kandou Manado menemukan bahwa dari jumlah sampel sebanyak 48 pasien penyakit ginjal kronik yang menjalani hemodialisis pada umumnya mempunyai nilai trombosit normal, jumlah kasus trombositopeni 25,45\%, dan angka kejadian terbanyak umumnya pada lakilaki. Berdasarkan penelitian Nurkamila dan Titiek Hidayati tahun 2013 di RSUD Panembahan Senopati Bantul menyimpulkan bahwa terdapat hubungan yang signifikan antara Angka Leukosit, Kadar Hemoglobin, danAngka Trombosit dengan kualitas hidup domain fisik penderita Gagal Ginjal Kronik Terminal (GGKT). Sementara Melti Tandi, dkk pada tahun 2014 di RSUP Prof. Dr. R. D. Kandou Manado menyimpulkan bahwa tidak terdapat hubungan yang signifikan antara penyandang Chronic Kidney Disease (CKD) non hemodialisa dengan nilai agregasi trombosit.

\section{Metode}

Jenis penelitian ini adalah deskriptif analitik. Penelitian dilaksanakan pada bulan Mei 2017, di RSUD dr. H. Abdul Moeloek Provinsi Lampung. Data yang digunakan dalam penelitian ini adalah data primer dan data sekunder. Data primer diperoleh dengan melakukan pemeriksaan nilai PDW, MPV, dan jumlah trombosit pasien gagal ginjal kronik pada pre dan post hemodialisa di RSUD dr. H. Abdul Moeloek Provinsi Lampung. Sedangkan data sekunder diperoleh dengan mencatat data nama, umur, jenis kelamin, dan jumlah terapi hemodialisa pasien dari rekam medis pasien di RSUD dr. H. Abdul Moeloek Provinsi Lampung.

Alat dan bahan yang digunakan dalam pemeriksaan ini adalah handskun, spuit, torniquet, tabung darah EDTA, dan Alat Sysmex XP-100, dan alcohol swab $70 \%$. Bahan pemeriksaan yang digunakan adalah darah vena pasien gagal ginjal kronik pada pre dan post hemodialisa di RSUD dr. H. Abdul Moeloek Provinsi Lampung, yang berjumlah 30 pasien. Data yang didapatkan diolah dengan menggunakan Uji t Paired sample test.

\section{Hasil dan Pembahasan}

1. Analisa univariat

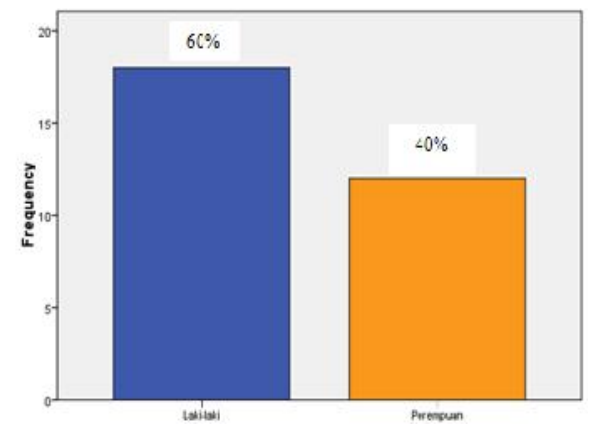

Gambar 1. Distribusi Frekuensi Berdasarkan Jenis Kelamin

Berdasarkan data hasil penelitian, menunjukan frekuensi responden penelitian terbanyak pasien penderita gagal ginjal kronik yang menjalani hemodialisa di RSUD dr. $H$. Abdul MoeloekProvinsi Lampung adalah pasien dengan jenis kelamin laki- laki, sebanyak 18 pasien $(60.0 \%)$, sedangkan pasien 
dengan jenis kelamin perempuan sebanyak 12 pasien $(40.0 \%)$.

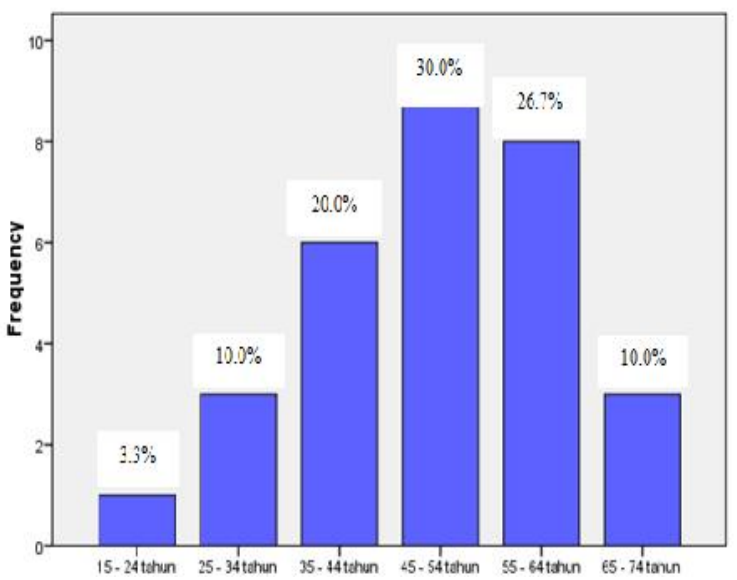

Gambar 2. Distribusi Frekuensi Berdasarkan umur

Berdasarkan data hasil penelitian menunjukan distribusi usia responden penelitian terbanyak pasien penderita gagal ginjal kronik yang menjalani hemodialisa di RSUD dr. H. Abdul Moeloek Provinsi Lampung adalah pasien berusia 45 - 54 tahun, sebanyak 9 pasien $(30.0 \%)$. Dan usia responden penelitian paling sedikit adalah pasien berusia 15 - 24 tahun, sebanyak 1 pasien $(3.3 \%)$.

Data hasil penelitian menunjukkan pasien penderita gagal ginjal kronik yang menjalani hemodialisa,dengan distribusi pasien jenis kelamin laki- laki sebanyak 18 pasien $(60.0 \%)$ dan pasien jenis kelamin perempuan sebanyak 12 pasien $(40.0 \%)$, artinya penderita gagal ginjal kronik yang menjalani hemodialisa dengan jenis kelamin laki- laki lebih banyak dibandingkan dengan penderita gagal ginjal kronik yang menjalani hemodialisa dengan jenis kelamin perempuan. Hasil penelitian ini sejalan dengan penelitian Wicaksono (2009) yang menunjukkan bahwa prevalensi kejadian ginjal kronis lebih besar terjadi pada laki-laki. Hal ini dikarenakan kecenderungan laki-laki yang kurang memperhatikan pola hidup. Pola hidup yang dimaksud salah satunya yaitu seringnya mengkonsumsi minuman berenergi yang mengandung kafein, taurin, mineral, dan glukosa. Zat-zat inilah yang berbahaya bagi kesehatan ginjal dan menjadi penyebab kejadian gagal ginjal kronik. Jika semakin sering dikonsumsi maka glomerulus akan mengalami kematian sel, kehancuran sel, dan kapsula bowman berongga, sehingga menyebabkan kerusakan ginjal yang semakin cepat dan mempengaruhi stadium gagal ginjal (Nugroho, 2015).

Data hasil penelitian menunjukkan bahwa usia responden penelitian yaitu pasien penderita gagal ginjal kronik yang menjalani hemodialisa terbanyak yaitu responden dengan rentang usia 45 - 54 tahun dengan jumlah 9 pasien $(30.0 \%)$. Sesuai dengan data prevalensi kelompok umur berdasarkan Riskesdas (2013) dimana terjadi peningkatan jumlah pasien gagal ginjal kronik yang menjalani terapi hemodialisa seiring dengan bertambahnya usia. Hal ini disebabkan karena semakin bertambah usia, semakin berkurang fungsi ginjal dan berhubungan dengan penurunan kecepatan ekskresi glomerulus dan memburuknya fungsi tubulus. Penurunan fungsi ginjal dalam skala kecil merupakan proses normal bagi setiap manusia seiring bertambahnya usia, namun tidak menyebabkan kelainan atau menimbulkan gejala karena masih dalam batas-batas wajar yang dapat ditoleransi ginjal dan tubuh.

Tabel 1. Distribusi frekuensi Nilai PDW, MPV, dan Jumlah Trombosit pada Pre dan Post Hemodialisa Penderita Gagal Ginjal Kronik

\begin{tabular}{cccccccccc}
\hline & \multicolumn{4}{c}{ Pre Hemodialisa } & \multicolumn{4}{c}{ Post Hemodialisa } \\
\cline { 2 - 9 } Variabel & $\begin{array}{c}\text { Mean / } \\
\text { Rata- } \\
\text { rata }\end{array}$ & $\begin{array}{c}\text { Nilai } \\
\text { Minimum }\end{array}$ & $\begin{array}{c}\text { Nilai } \\
\text { Maksimum }\end{array}$ & SD & $\begin{array}{c}\text { Mean / } \\
\text { Rata-rata }\end{array}$ & $\begin{array}{c}\text { Nilai } \\
\text { Minimum }\end{array}$ & $\begin{array}{c}\text { Nilai } \\
\text { Maksimu } \\
\text { m }\end{array}$ & SD \\
\hline PDW & 12,95 & 10,50 & 17,40 & 1,6 & 12,28 & 9,30 & 17,50 & 2,1 \\
\hline MPV & 9,97 & 9,00 & 11,50 & 0,6 & 9,92 & 8,50 & 11,70 & 0,7 \\
\hline Jumlah Trombosit & 462.100 & 147.000 & 1.072 .000 & 2,1 & 277.666 & 106.000 & 798.000 & 1,5 \\
\hline
\end{tabular}

Data hasil penelitian menunjukkan nilai rata-rata PDW pre hemodialisa didapatkan sebesar $12.95 \mathrm{fL}$, nilai rata-rata PDW post hemodialisa didapatkan sebesar $12.28 \mathrm{fL}$, nilai rata-rata MPV pre hemodialisa didapatkan sebesar $9.97 \mathrm{fL}$, nilai rata-rata MPV post hemodialisa didapatkan sebesar $9.92 \mathrm{fL}$, nilai rata-rata jumlah trombosit pre hemodialisa didapatkan sebesar $462,100 / \mathrm{mm}^{3}$, dan nilai rata-rata jumlah trombosit post hemodialisa didapatkan sebesar $277,666 / \mathrm{mm}^{3}$. 
Tabel 2. Hasil Analisa Univariat Nilai PDW, MPV, dan Jumlah Trombosit pasien gagal ginjal kronik pada Pre dan Post Hemodialisa di RSUD dr. H. Abdul Moeloek Provinsi Lampung

\begin{tabular}{|c|c|c|c|}
\hline No. & Variabel & Jumlah Pasien & Persentase (\%) \\
\hline \multirow[t]{5}{*}{1.} & Pre Hemodialisa & & \\
\hline & Rendah & & \\
\hline & Normal & 0 & 0 \\
\hline & Tinggi & 2 & 6,7 \\
\hline & & 28 & 93,3 \\
\hline \multirow[t]{5}{*}{2.} & Post Hemodialisa & & \\
\hline & Rendah & & \\
\hline & Normal & 0 & 0 \\
\hline & Tinggi & 9 & 30 \\
\hline & & 21 & 70 \\
\hline \multirow[t]{5}{*}{3.} & Pre Hemodialisa & & \\
\hline & Rendah & & \\
\hline & Normal & 0 & 0 \\
\hline & Tinggi & 28 & 93,3 \\
\hline & & 2 & 6,7 \\
\hline \multirow[t]{5}{*}{4.} & Post Hemodialisa & & \\
\hline & Rendah & & \\
\hline & Normal & 0 & 0 \\
\hline & Tinggi & 28 & 93,3 \\
\hline & & 2 & 6,7 \\
\hline \multirow[t]{5}{*}{5.} & Jumlah Trombosit Pre Hemodialisa & & \\
\hline & Rendah & & \\
\hline & Normal & 1 & 3,3 \\
\hline & Tinggi & 13 & 43,3 \\
\hline & & 16 & 53,3 \\
\hline \multirow[t]{5}{*}{6.} & Jumlah Trombosit Post Hemodialisa & & \\
\hline & Rendah & & \\
\hline & Normal & 5 & 16,7 \\
\hline & Tinggi & 22 & 73,3 \\
\hline & & 3 & 10,0 \\
\hline
\end{tabular}

Berdasarkan data hasil penelitian hasil penelitian menunjukkan bahwa nilai PDW pre hemodialisa dengan kategori diatas nilai normal sebanyak 28 pasien (93.3\%), nilai PDW post hemodialisa dengan kategori diatas nilai normal sebanyak 21 pasien $(70.0 \%)$, nilai MPV pre hemodialisa dengan kategori nilai normal sebanyak 28 pasien (93.3\%), nilai MPV post hemodialisa dengan kategori nilai normal sebanyak 28 pasien (93.3\%), jumlah trombosit pre hemodialisa dengan

kategori diatas nilai normal sebanyak 16 pasien (53.3\%), dan jumlah trombosit post hemodialisa dengan kategori sesuai dengan nilai normal sebanyak 22 pasien (73.3\%).

\section{Analisa Bivariat}

Tabel 3. Hasil Uji t nilai PDW, MPV, dan jumlah trombosit pasien gagal ginjal kronik pada Pre dan Post Hemodialisa di RSUD dr. H. Abdul Moeloek Provinsi Lampung

\begin{tabular}{|c|c|c|c|c|c|c|}
\hline Variable & Mean & $\begin{array}{c}\text { Std. } \\
\text { Deviation }\end{array}$ & Std. Error Mean & $\begin{array}{c}\mathbf{P} \\
\text { Value }\end{array}$ & $\mathbf{N}$ & $\begin{array}{c}\alpha \\
\text { value }\end{array}$ \\
\hline $\begin{array}{l}\text { Nilai PDW pasien GGK } \\
\text { pada pre dan post } \\
\text { hemodialisa }\end{array}$ & 0.667 & 2.069 & 0.377 & 0.088 & 30 & 0.050 \\
\hline $\begin{array}{l}\text { Nilai MPV pasien GGK } \\
\text { pada pre dan post } \\
\text { hemodialisa }\end{array}$ & 0.050 & 0.770 & 0.140 & 0.725 & 30 & \\
\hline $\begin{array}{l}\text { Jumlah Trombosit } \\
\text { pasien GGK pada pre } \\
\text { dan post hemodialisa }\end{array}$ & 0.227 & 0.258 & 0.047 & 0.000 & 30 & \\
\hline
\end{tabular}


Berdasarkan data hasil penelitian data hasil uji T Paired Sample Test pada jumlah trombosit didapatkan nilai $p$-value $=0.000$, artinya $\mathrm{Ha}$ diterima, hal ini berarti terdapat perbedaan bermakna pada jumlah trombosit pre dan post hemodialisa pada pasien gagal ginjal kronik. Pada data hasil uji T Paired Sample Test nilai PDW didapatkan nilai $p$-value $=$ 0.088 , artinya Ha ditolak, hal ini berarti tidak terdapat perbedaan bermakna pada nilai PDW pre dan post hemodialisa pada pasien gagal ginjal kronik. Serta data hasil uji T Paired Sample Test pada nilai MPV didapatkan nilai $p$ value $=0.725$, artinya Ha ditolak, hal ini berarti tidak terdapat perbedaan bermakna pada nilai MPV pre dan post hemodialisa pada pasien gagal ginjal kronik.

Hasil analisa statisik yang telah dilakukan dengan uji t-test, menunjukkan tidak terdapat perbedaan nilai bermakna pada nilai PDW dan MPV pre dan post hemodialisa pasien gagal ginjal kronik, dengan $p$-value $\mathrm{PDW}=0.088$ dan $p$-value $\mathrm{MPV}=0.725(p>$ 0.050 ), sedangkan pada jumlah trombosit pre dan post hemodialisa pasien gagal ginjal kronik menunjukkan terdapat perbedaan nilai bermakna dengan nilai $p$-value 0.000 ( $p<$ 0.050). Pemeriksaan nilai PDW darah dilakukan untuk melihat ragaman atau variasi ukuran rerata isi trombosit dalam darah dan pemeriksaan nilai MPV dalam darah dilakukan untuk mengukur ukuran trombosit yang merupakan petanda fungsi trombosit dan berhubungan dengan penunjuk aktivitas trombosit (Gunawan, dkk, 2010).Pemeriksaan jumlah trombosit dilakukan untuk mengetahui jumlah trombosit dalam darah karena fungsi dan peran trombosit dalam darah yang sangat penting yaitu melindungi integritas endotel pembuluh darah dan memulai perbaikan apabila terjadi kerusakan pada dinding pembuluh darah.

Hasil penelitian menunjukkan bahwa nilai PDW dan MPV pasien gagal ginjal kronik pre dan post hemodialisa tidak memiliki perbedaan nilai yang bermakna dan tidak dipengaruhi oleh jumlah trombosit pasien yang ditemukan. Hasil nilai PDW pada penelitian ini sejalan dengan hasil penelitian Gunawan, dkk (2010) yang telah melakukan penelitian tentang Hubungan Nilai PDW dan MPV dengan Derajat Penyakit Demam Berdarah Dengue, didapatkan hasil korelasi negatif antara jumlah trombosit dengan nilai PDW $(\mathrm{r}=-0.770 ; p<$ 0.05) dan MPV ( $\mathrm{r}=-0.523 ; p<0.05)$, berarti semakin rendah jumlah trombosit yang didapatkan maka semakin tinggi nilai PDW dan MPV yang ditemukan. Tetapi untuk hasil nilai
MPV pada penelitian ini tidak sejalan dengan penelitian yang telah dilakukan oleh Gunawan, dkk (2010).

Hasil data penelitian menunjukkan 4 pasien mengalami kenaikan nilai jumlah trombosit setelah menjalani proses hemodialisa. Faktor yang mempengaruhi yaitu pada saat proses penarikan cairan dari dalam tubuh pasien oleh mesin hemodialisa (proses difusi) yang menyebabkan cairan dalam tubuh pasien menjadi lebih pekat, sementara data penelitian menunjukkan 26 pasien mengalami penurunan jumlah trombosit setelah menjalani proses hemodialisa. Faktor yang mempengaruhi yaitu pemberian heparin dan pemasangan akses selang mesin hemodialisa yang tidak sesuai di pembuluh darah pasien, sehingga menyebabkan proses pencucian darah tidak lancar karena adanya kontak udara.

Hasil penelitian menunjukkan nilai trombosit normal pada 22 pasien $(73.3 \%)$ setelah melakukan terapi hemodialisa. Bila dilakukan pengontrolan yang ketat terhadap pemberian heparin tidak akan memberikan efek samping yang banyak terhadap nilai trombosit (Kaparang, dkk, 2013). Heparin adalah glikoasaminoglikan bermuatan negatif yang dilepaskan oleh sel mast dan basofil selama proses pembekuan darah normal. Heparin dipakai untuk penanganan dan profilaksis penyakit tromboemboli. Trombositopenia akibat heparin merupakan kelainan protrombotik, dimediasi oleh antibodi IgG yang berikatan dengan epitop di Platelet Factor 4 (PF4) dan membentuk kompleks dengan heparin. Umumnya jumlah trombosit menurun sedang, bisa juga terjadi trombositopenia, tetapi jumlah trombosit turun lebih dari 50\% dari jumlah trombosit tertinggi sebelum terapi (Roveny, 2016).

Hasil penelitian menunjukkan terdapat 5 pasien (16.7\%) dengan kasus mengalami trombositopenia yang menunjukkan adanya efek samping dari pemberian heparin. Resiko trombositopenia akibat heparin berkaitan dengan durasi paparan heparin dan molekul heparin.Data pada penelitian sebelumnya yang telah dilakukan oleh Kaparang, dkk (2013) menunjukkan bahwa sebanyak 15 pasien gagal ginjal kronik (33.33\%) mengalami kasus trombositopenia. Kejadian trombositopenia akibat heparin biasanya terjadi 5-10 hari setelah terapi heparin dimulai, baik pada pasien yang mendapat heparin untuk pertama kali maupun paparan ulang, kecuali trombositopenia akibat heparin onset cepat yang ditandai dengan penurunan drastis trombosit beberapa jam 
setelah terapi heparin. Keadaan tersebut terjadi pada pasien telah terpapar heparin sebelumnya, yang telah memiliki antibodi PF4-heparin. Kasus trombositopenia akibat heparin tidaklah jarang, dan sering tidak terdiagnosis atau justru overdiagnosis karena sering bermanifestasi bersama penyebab lain trombositopenia. Selain itu, pemeriksaan untuk mendiagnosis trombositopenia akibat heparin bersifat sensitif tetapi tidak spesifik (Roveny, 2016).

Diagnosis trombositopenia biasanya ditegakkan dengan menggunakan hasil analisa dari alat hematology analyzer. Namun, hasil penghitungan ini perlu diverifikasi dengan pemeriksaan apusan darah tepi. Verifikasi dengan pemeriksaan apusan darah tepi juga dapat menunjukkan penyebab lain dari jumlah trombosit yang rendah. Apabila jumlah trombosit pasien gagal ginjal yang telah menjalani terapi hemodialisa menurun, sebaiknya dilakukan proses transfusi trombosit yang bertujuan untuk mempertahankan nilai normal dari jumlah trombosit ketika terjadi pendarahan.

Kesimpulan penelitian ini yaitu dari 30 sampel darah responden didapatkan rata-rata nilai PDW pasien gagal ginjal kronik pada pre hemodialisa adalah $12,95 \mathrm{fL}$ dan post hemodialisa adalah 12,28 fL , rata-rata nilai MPV pre hemodialisa adalah 9,97 fL dan post hemodialisa adalah 9,92 fL, rata-rata jumlah trombosit pre hemodialisa adalah 462.100 $/ \mathrm{mm} 3$ dan post hemodialisa adalah $267.666 / \mathrm{mm} 3$. Terdapat perbedaan bermakna antara jumlah trombosit pasien gagal ginjal kronik pada pre dan post hemodialisa dengan $p$ value $=0,000(\mathrm{p}<0,05)$. Tidak terdapat perbedaan bermakna antara nilai PDW pasien gagal ginjal kronik pada pre dan post hemodialisa dengan $p$-value $=0,088(\mathrm{p}>0,05)$. Tidak terdapat perbedaan bermakna antara nilai MPV pasien gagal ginjal kronik pada pre dan post hemodialisa dengan $p$-value $=0,725(\mathrm{p}>$ $0,05)$.

\section{Daftar Pustaka}

1. Gunawan, S, Sutanto, FC, Tatura, SNN, Mantik, MFJ 2010, "Platelet DistributionWidth dan Mean Platelet Volume : Hubungan dengan Derajat PenyakitDemam Berdarah Dengue", di dalam Sari Pediatri, Badan Penerbit IkatanDokter Anak Indonesia, Volume 12, Jakarta, Halaman 74-77.
2. Haryono, R 2013, Keperawatan Medikal Bedah Sistem Perkemihan, Erlangga, Jakarta.

3. Hoffbrand, AV, Pettit, JE, Moss, PAH 2013, Kapita Selekta Hematologi, Edisi 6, EGC Kedokteran, Jakarta

4. Litbang, RI 2013, Laporan Nasional 2013 (online),(http://www.litbangkes.depkes.go. id/sites/download/rkd2013/Laporan.

Riskesdas.2013.PDF).

5. Kaparang, J, Moeis, ES, Rotty, L 2013, "Nilai Trombosit pada Pasien Penyakit Ginjal Kronik Yang Menjalani Hemodialisis Di Unit Hemodialisis Bagian/ SMF Ilmu Penyakit Dalam FK UNSRAT BLU RSUP Prof. Dr. R. D. Kandou Manado",di dalam Jurnal eBiomedik (eBM), Volume 1, PAAI Komisariat Manado, Manado, Halaman 95-100.

6. Perkumpulan Nefrologi Indonesia (PERNEFRI) dan Departemen Kesehatan RI,2012, 5th Report of Indonesian Renal Registry, Available at :(http://www.pernefri-inasn.org>Laporan Accessed January 10th,2017).

7. Price, SA, Wilson LM 2012, Patofisiologi Konsep Klinis Proses - proses Penyakit,Edisi 6, Volume 2, Penerbit Buku Kedokteran EGC, Jakarta.

8. Roveny 2016, "Trombositopenia Akibat Heparin", di dalam Cermin DuniaKedokteran, Volume 43, Kalbe Medical, Jakarta, Halaman 659-664.

9. Setiabudy, RD 2012, Hemostasis dan Trombosis, Balai Penerbit FKUI, Jakarta.Sacher, RA, McPherson RA 2012, Tinjauan Klinik Hasil Pemeriksaan Laboratorium,Penerbit Buku Kedokteran EGC, Jakarta.

10. Shah, AR, Chaudhari, SN, Shah, MH 2013, "Role Platelet Parameters In DiagnosingVarious Clinical Conditions", di dalam National Journal Of MedicalResearch, Volume 3, eJManajer All Rights Reserved, USA, Page 162-165.

11. Suharyanto, T, Abdul M 2013, Asuhan Keperawatan Medikal Bedah 
GangguanSistem Perkemihan, Trans Info Media, Jakarta.

12. Tandi, M, Mongan, A, Manoppo, F 2014, "Hubungan Antara Derajat Penyakit GinjalKronik Dengan Nilai Agregasi Trombosit Di RSUP Prof. Dr. R. D. KandouManado", di dalam Jurnal e-
Biomedik (eBM), Volume 2, PAAI KomisariatManado, Manado, Halaman 509-513.

13. Tarwoto, Wartonah 2008, Keperawatan Medikal Bedah Gangguan SistemHematologi, Trans Info Media, Jakarta. 